\begin{tabular}{|c|c|c|}
\hline $\begin{array}{l}\text { EREM 74/2 } \\
\text { Journal of Environmental Research. }\end{array}$ & \multicolumn{2}{|c|}{$\begin{array}{l}\text { Procedure of Landscape Anthropization Extent Modeling: } \\
\text { Implementation for Ukrainian Physic-Geographic Taxons }\end{array}$} \\
\hline $\begin{array}{l}\text { Vol. } 74 / \text { No. } 2 \text { / } 2018 \\
\text { pp. } 67-81\end{array}$ & Received 2018/04 & Accepted after revision 2018/05 \\
\hline $\begin{array}{l}\text { DOI 10.5755/j01.erem.74.2.20646 } \\
\text { () Kaunas University of Technology }\end{array}$ & \multicolumn{2}{|c|}{ Crossef http://dx.doi.org/10.5755/j01.erem.74.2.20646 } \\
\hline
\end{tabular}

\title{
Procedure of Landscape
} Anthropization Extent Modeling: Implementation for Ukrainian Physic-Geographic Taxons

\section{Viktor Samoilenko, Ivan Dibrova}

Taras Shevchenko National University of Kyiv, 2A, Glushkov Prospekt, Kyiv, 03680 Ukraine

\section{Volodymyr Osadchyi}

Ukrainian hydrometeorological institute, National Academy of Science of Ukraine, 37, Nauky Prospect, Kyiv, 02000 Ukraine

\section{Liubov Vishnikina}

V.G. Korolenko National Pedagogic University of Poltava, 2, Ostrogradskyi Street, Poltava, 36003 Ukraine

Corresponding author: viksam1955@gmail.com

V. Samoilenko, Taras Shevchenko National University of Kyiv 2A, Glushkov Prospekt, Kyiv, 03680 Ukraine

The procedure of anthropization extent modeling for landscapes and/or physic-geographic taxons was implemented for the specified megaregion. It includes Ukrainian physic-geographic zones of mixed and broad-leaved forests and forest-steppe. The spatial data bases (SDB) were organized for the implementation megaregion by appropriate geoinformation processing of up-to-date open digital spatial data sources. The implementation operating scale of anthropization extent for physic-geographic taxons was substantiated and created in accordance with the megaregional SDB. The scale embodies 55 operating land use and/or land cover (LULC) systems causing determinate anthropization extent. The last is presented by corresponding to mentioned systems anthropization categories and indexes. The operating scale was strictly implemented for the megaregion. The implementation included the anthropization extent modeling at the level of physic-geographic areas and districts. The interpretation of the obtained model results was carried out. The results display that the land use consequences are altogether unfavorable for the natural environment of the megaregion. 
The model implementation achievements indicated the relevance and objectivity of proposed approaches to the landscape anthropization extent modeling. The approaches are applicable to schemes and projects of environmental management.

Keywords: landscape, anthropization, modeling, spatial data bases, physic-geographic taxon

\section{Introduction}

According to the European Landscape Convention the primary task of advanced environmental research, engineering and management is the study of landscapes' anthropization in order to manage it. Such anthropization is a process of landscape transformation in consequence of human impact on them and/or their aggregations. The actual tasks of the European countries are also the monitoring and the analysis of their landscape anthropization and factors of such process. International exchange of relevant positive for natural environment experience and information is planned too.

In our previous publications (Samoilenko, 2002, 2003; Osadchyi, Samoilenko et al., 2004; Samoilenko, Dibrova, 2012; Samoilenko, Vishnikina et al., 2014; Samoilenko et al., 2006, 2015a, 2015b, 2016a, 2016b, 2017; Samoilenko, Dibrova et al., 2018) there were substantiated and realized the theoretic-applied approaches to the modeling of an anthropogenic (human) impact on other level geosystems. Such geosystems represent the different landscape territorial structures, viz. river basin, biotic-landscape, network, positional-dynamic, geotone and some other structures.

In our recent scientific papers and monograph (Samoilenko et al., 2015b, 2016a, 2016b, 2017; Samoilenko, Dibrova et al., 2018) the new conceptual foundations and the procedure of anthropization extent modeling for landscapes and/or taxons of physic-geographic zoning were also substantiated and developed. Such taxons are interpreted as landscape aggregations in the form of regional landscape structures. The mentioned procedure is originated for the first time as a result of creative synthesis of the European hemeroby conception and the Ukrainian geoecological-nature-management analysis conception. That's why this procedure is interoperable for all-European and Ukrainian approaches.
The procedure of landscape anthropization extent modeling needs the verifying realization for different by size and conditions territories. So the principal purpose of this paper was to implement the above mentioned developed procedure for the specified megaregion called further, briefly, the implementation megaregion. It consists of Ukrainian physic-geographic zones of mixed (coniferous / broad-leaved) and broad-leaved forests and forest-steppe and their physic-geographic taxons of the lower level. Such zones according to the physic-geographic zoning of Ukraine (National Atlas, 2007) include zones' physic-geographic regions called "kray" in Ukrainian. The last consist of physic-geographic areas called "oblast"' in Ukrainian, which are divided into physic-geographic districts or "rayon" in Ukrainian. Therefore this paper had three specific tasks. The first one was to organize relevant accessible modern spatial data bases for the implementation megaregion. Such bases further will be called the implementation spatial data bases or SDB. The second task was to create the operating scale of physic-geographic taxons' anthropization extent according to the implementation SDB. This scale further will be called briefly the implementation operating scale or simply the operating scale. And the third task was to implement strictly the operating scale for the implementation megaregion. The last task also included the anthropization extent modeling for the physic-geographic areas and districts with the interpretation of obtained model results.

\section{Methods}

Chosen for implementation, the model procedure is based primary on the interoperable common-matter classified scheme of the landscape and/or physical-geographic taxons' anthropization extent. The last 
depends on the anthropogenic impact extent of land use and/or land cover (LULC) systems. This impact is specified by the corresponding degrees of hemeroby, impact intensity, geoecological positivity / negativity and naturalness of LULC systems. Operating version for the classified scheme is presented in the Table 1. Such version defines seven principal categories (1-7) of the landscape / taxon anthropization extent and corresponding to them categories of LULC systems' geoecological positivity / negativity. Some subcategories (4a, 4b, 5a and 5b) also are defined.

The scheme in the Table 1 uses the non-linear parameterized by septiles (Samoilenko et.al. 2017, 2018) categorical ranges for the values of one of the procedure's model/estimation tools. Such tool is the index of anthropization, average-weighted by the areas of

\section{Table 1}

Operating version for the interoperable classified scheme of the landscape and/or physic-geographic taxons' anthropization extent 1)

\begin{tabular}{|c|c|c|c|c|c|}
\hline \multirow{2}{*}{$\begin{array}{l}\text { Code and name of } \\
\text { landscape / taxon } \\
\text { anthropization extent } \\
\text { category }\end{array}$} & \multicolumn{3}{|c|}{ Extent of anthropogenic impact for LULC systems: } & \multirow{2}{*}{$\begin{array}{l}\text { Categorical ranges } \\
\text { for values of } \\
\text { anthropization index } \\
I_{A N T^{* *}} \text { in formula (1) }\end{array}$} & \multirow{2}{*}{$\begin{array}{l}\text { Color of } \\
\text { category at } \\
\text { thematic } \\
\text { choropleths }\end{array}$} \\
\hline & $\begin{array}{l}\text { Hemeroby degree and } \\
\text { anthropogenic impact } \\
\quad \text { intensity }{ }^{2)}\end{array}$ & $\begin{array}{l}\text { Geoecological } \\
\text { positivity / } \\
\text { negativity }\end{array}$ & $\begin{array}{c}\text { Degree of } \\
\text { naturalness }{ }^{3)}\end{array}$ & & \\
\hline 1 & 2 & 3 & 4 & 5 & 6 \\
\hline $\begin{array}{l}1-\text { Very slight } \\
\text { anthropization }\end{array}$ & $\begin{array}{l}\text { Ahemerobic, } \\
\text { almost no impact }\end{array}$ & $\begin{array}{l}\text { Very geo- } \\
\text { positive }\end{array}$ & Natural & $(0 \ldots 15,8]$ & \\
\hline $\begin{array}{l}2 \text { - Slight } \\
\text { anthropization }\end{array}$ & $\begin{array}{l}\text { Oligohemerobic, } \\
\text { weak impact }\end{array}$ & Geo-positive & Close to natural & $(15,8 \ldots 28,3]$ & \\
\hline $\begin{array}{l}3 \text { - Moderate } \\
\text { anthropization }\end{array}$ & $\begin{array}{l}\text { Mesohemerobic, } \\
\text { moderate impact }\end{array}$ & $\begin{array}{l}\text { Moderately geo- } \\
\text { positive }\end{array}$ & Semi-natural & $(28,3 \ldots 39,2]$ & \\
\hline $\begin{array}{l}\text { 4a - L/c moderate- } \\
\text { great anthropization }\end{array}$ & $\begin{array}{c}\text { L/c } \beta \text {-euhemerobic, } \\
\text { l/c moderate-strong } \\
\text { impact }\end{array}$ & $\begin{array}{l}\text { L/c moderately } \\
\text { geo-negative }\end{array}$ & $\begin{array}{l}\text { L/c relatively far } \\
\text { from natural }\end{array}$ & $(39,2 \ldots 44,8]$ & \\
\hline $\begin{array}{l}\text { 4b-H/c moderate- } \\
\text { great anthropization }\end{array}$ & $\begin{array}{c}\mathrm{H} / \mathrm{c} \beta \text {-euhemerobic, } \\
\mathrm{h} / \mathrm{c} \text { moderate-strong impact }\end{array}$ & $\begin{array}{l}\text { H/c moderately } \\
\text { geo-negative }\end{array}$ & $\begin{array}{l}\mathrm{H} / \mathrm{c} \text { relatively } \\
\text { far from natural }\end{array}$ & $(44,8 \ldots 50,4]$ & \\
\hline $\begin{array}{l}5 a-L / c \text { great } \\
\text { anthropization }\end{array}$ & $\begin{array}{l}\text { L/c a-euhemerobic, } \\
\text { strong impact }\end{array}$ & $\begin{array}{l}\mathrm{L} / \mathrm{c} \text { geo- } \\
\text { negative }\end{array}$ & $\begin{array}{l}\text { L/c far from } \\
\text { natural }\end{array}$ & $(50,4 \ldots 57,1]$ & \\
\hline $\begin{array}{l}5 \mathrm{~b}-\mathrm{H} / \mathrm{c} \text { great } \\
\text { anthropization }\end{array}$ & $\begin{array}{l}\text { H/c a-euhemerobic, } \\
\text { strong impact }\end{array}$ & $\begin{array}{l}\mathrm{H} / \mathrm{c} \text { geo- } \\
\text { negative }\end{array}$ & $\begin{array}{l}\text { H/c far from } \\
\text { natural }\end{array}$ & $(57,1 \ldots 63,7]$ & \\
\hline $\begin{array}{l}6 \text { - Very great } \\
\text { anthropization }\end{array}$ & $\begin{array}{l}\text { Polyhemerobic, } \\
\text { very strong impact }\end{array}$ & $\begin{array}{l}\text { Very geo- } \\
\text { negative }\end{array}$ & $\begin{array}{l}\text { Strange to } \\
\text { natural }\end{array}$ & $(63,7 \ldots 79,5]$ & \\
\hline $\begin{array}{l}7 \text { - Excessive } \\
\text { anthropization }\end{array}$ & $\begin{array}{c}\text { Metahemerobic, } \\
\text { excessively strong impact }\end{array}$ & $\begin{array}{l}\text { Excessively } \\
\text { geo-negative }\end{array}$ & Artificial & $(79,5 \ldots 100]$ & \\
\hline
\end{tabular}

\footnotetext{
1) Based on (Samoilenko et.al. 2015b, 2016a, 2016b, 2017; Samoilenko, Dibrova et al., 2018). Abbreviation: L/c - low-categorical, H/c - high-categorical

2) According to (Walz, Stein, 2014) and (IOER Monitor, 2018) with our modification

3) According to (Paracchini, Capitani, 2011) and (Eurostat Statistics, 2012) with our modification

4) Synonyms to choropleth are choropleth map, or cartogram, or value-by-area map
} 
proper LULC systems for definite landscape and/or physic-geographic taxon $\left(I_{A N T^{* *}}, \%\right)$. It is calculated by the formula

$$
I_{A N T} * *=\sum_{i=1}^{n} I_{A N T, E, i} \cdot s_{i}
$$

Where: $I_{A N T, E, i}$ - the calculating anthropization index. It is partial for the relevant (i) LULC system of definite landscape and/or physic-geographic taxon. The index finally is determined in percents from the Table 2 (see further operating scale); $s_{i}$ - the total part of the mentioned LULC system's area with $I_{A N T, E, i}$ It is used in fractions of a unity, provided that the total terrestrial area of the landscape/taxon is equal to $1 ; n$ - number of calculating by Table 2 LULC systems within boundaries of a landscape/taxon.

For the second, model procedure involves the interoperable generalized scale of anthropization extent for terrestrial landscapes or their aggregations. This extent is caused by various the highest level LULC systems (see the Table 3 in (Samoilenko et al., 2017)). Such scale uses the appropriate possible ranges and mean values for anthropization extent categories, named in the first column of the Table 1. The scale uses also the partial anthropization indexes $I_{A N T, E, i}$ according to the formula (1). They reflect the anthropogenic impact of ranged 13 first-level LULC systems with their elements.
For the third, the principles and approaches to transforming the mentioned initial generalized scale of anthropization extent into the operating scale were proposed (see (Samoilenko et al., 2016b, 2018)).

\section{Results and Discussion}

\section{Implementation Spatial Data Bases (SDB)}

According to (National Atlas, 2007) three physic-geographic zones of the implementation megaregion have the total model area, i.e. area without water bodies, of approximately 310 thousands $\mathrm{km}^{2}$. These zones include 5 physic-geographic regions. The regions are divided into 25 physic-geographic areas with their 130 physic-geographic districts (Fig.1-2 and later Fig.6). The implementation spatial data bases were organized for such megaregion by the appropriate geoinformation processing of up-to-date accessible open digital spatial data sources. Such sources were layer-based vectorized with reclassification of their spatial features. The sources contain, firstly, interactive raster land cover map generated by the European Space Agency (ESA, 2015). The map is initially obtained from remote sensing data of satellite programs' set. The map has $300 \mathrm{~m}$ spatial resolution and

Fig. 1

Digital map of the implementation megaregion: the physic-geographic zones and regions

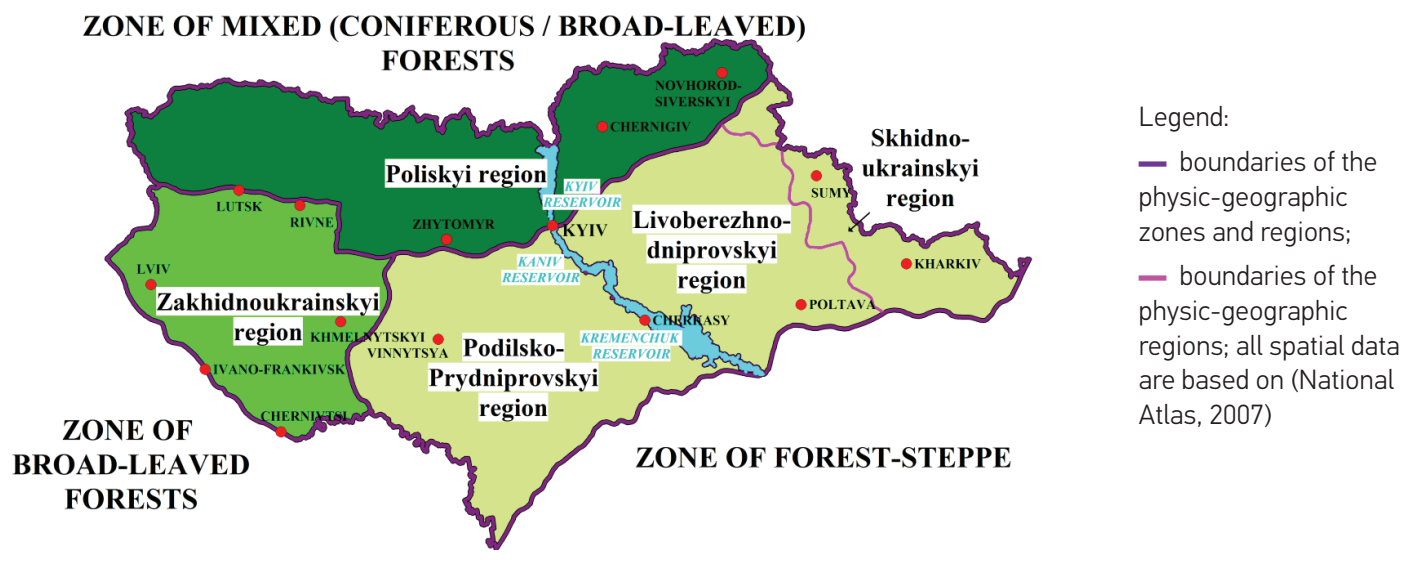


Fig. 2

Digital map of the implementation megaregion: the physic-geographic areas

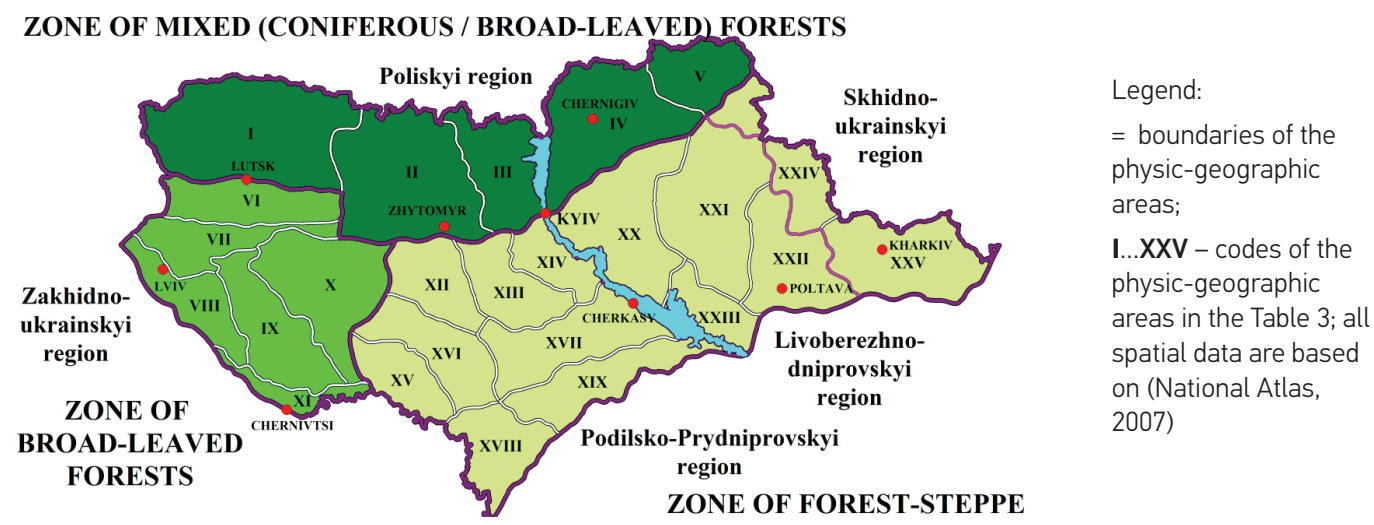

corresponds to the classification used for its creation. Such classification operates 22 first-level classes and 14 subclasses of the land covers. The second source is similar to previous map generated by the National Geomatics Center of China (NGCC, 2011). This map has already $30 \mathrm{~m}$ spatial resolution. It uses 10 types of the land covers including integrated by composition, e.g. the cover of artificial surfaces etc. The third source includes subject raster electronic maps collected in the National Atlas of Ukraine (National Atlas, 2007). The fourth source is represented by data of the cartographic web-services OpenStreetMap, Google Earth and Google Maps and some other representative services.

\section{Implementation Operating Scale}

The operating scale of anthropization extent for physic-geographic taxons was substantiated and developed primary according to the content and composition of the implementation SDB described in the previous item. The classification principles outlined in (Samoilenko et al., 2017) and (Bossard et al., 2000) were also considered. The scale in the Table 2 embodies 55 operating LULC systems causing determinate anthropization extent. This extent is presented by the corresponding to mentioned systems categories and partial indexes.

Some principal development and implementation peculiarities of the operating scale in the Table 2 are the following.
In case of different LULC systems overlay, an existing nature-protection system is always dominant. Also, systems with a higher index $I_{\text {ANT,E, }}$ have the advantage of selecting for the next modeling.

The multistage differentiation was applied to the arable and fallow land system marked V.7 in the Table 2. Firstly, the non-forest tilled system (V.7.1) and the forest tilled system (V.7.2) were identified. The last system is more sensitive to a transformation by consequences of the arable land use. This system in turn was divided according to anthropization index increase into the broad-leaved forest, mixed forest and coniferous forest tilled systems (V.7.2.1- V.7.2.3). The reason for this is that the soil cover and other components of different forest geosystems have the diverse vulnerability to transformation into the arable land. This vulnerability consistently increases from the broad-leaved to the coniferous forest geosystems (Samoilenko et al. 2015b, 2016a, 2016b). The impossibility of restoring the original natural properties of such geosystems increases in the same order.

In addition all four categorized by the aforementioned method systems (V.7.1 and V.7.2.1- V.7.2.3) were differentiated in the ranges of the given to them calculating partial anthropization indexes. Such differentiation displays the increasing values of these systems' surface slope. As a result the slightly, moderately, middling, essentially and greatly sloping relevant 


\section{Table 2}

Operating scale of physic-geographic taxons' anthropization extent, caused by the different level land use and/or land cover (LULC) systems

\begin{tabular}{|c|c|c|}
\hline Code and name of LULC systems for different levels & LULC systems' short name and code & $\begin{array}{l}\text { Anthropization extent for } \\
\text { physic-geographic taxon * }\end{array}$ \\
\hline 1 & 2 & 3 \\
\hline I - Nature-protection system, in particular: & & 1,2 \\
\hline $\begin{array}{l}\text { I.1 - Natural and biosphere reserves and protected natural } \\
\text { territories of international significance }\end{array}$ & NATURE PROTECTION - I.1 & $1 / 7.9 \%$ \\
\hline $\begin{array}{l}\text { I.2 - Protected zones of national natural and regional } \\
\text { landscape parks, another protected natural territories of } \\
\text { national significance, incl. reserve tracts }\end{array}$ & NATURE PROTECTION - I.2 & $2 / 22.1 \%$ \\
\hline II - Wetland system (incl. marshes, bogs, strictly wetlands etc.) & WETLANDS - ॥ & $2 / 20.0 \%$ \\
\hline III - Forestry system, in particular: & & 2 \\
\hline III.1 - Broad-leaved forest system & BROAD-LEAVED FORESTS - III.1 & $2 / 26.4 \%$ \\
\hline III.2 - Coniferous forest system & CONIFEROUS FORESTS - III.2 & 2 / $27.7 \%$ \\
\hline III.3 - Mixed forest system & MIXED FORESTS - III.3 & 2 / $27.7 \%$ \\
\hline IV - Shrubby-herbaceous natural system & SHRUBS-HERBS - IV & $3 / 33.7 \%$ \\
\hline V - Agricultural system, incl.: & & $3-6$ \\
\hline V.1-2 - Grassland-pasture and haymaking system & GRASS.-PASTURES \& HAYMAKING - V.1-2 & $3 / 36.0 \%$ \\
\hline V.5-6 - Fruit trees and vineyard system & FRUIT TREES \& VINEYARDS - V.5-6 & $5 a / 53.8 \%$ \\
\hline V.7 - Arable and fallow land system, in particular: & & $\begin{array}{c}(4 b \ldots . .6] / \\
(44.8 \% \ldots 79.5 \%]\end{array}$ \\
\hline $\begin{array}{l}\text { V.7.1 - Non-forest tilled system, incl. according } \\
\text { to surface slope: }\end{array}$ & & $\begin{array}{c}(4 b \ldots . .5 b] / \\
(44.8 \% \ldots 63.7 \%]\end{array}$ \\
\hline V.7.1.1 - slightly sloping & TILLED NON-FORESTS SL. SL. - V.7.1.1 & $4 b / 46.7 \%$ \\
\hline V.7.1.2 - moderately sloping & TILLED NON-FORESTS MOD. SL. - V.7.1.2 & $5 a / 50.5 \%$ \\
\hline V.7.1.3 - middling sloping & TILLED NON-FORESTS MID. SL. - V.7.1.3 & $5 a / 54.3 \%$ \\
\hline V.7.1.4-essentially sloping & TILLED NON-FORESTS ESS. SL. - V.7.1.4 & $5 b / 58.0 \%$ \\
\hline V.7.1.5 - greatly sloping & TILLED NON-FORESTS GR. SL. - V.7.1.5 & $5 b / 61.8 \%$ \\
\hline V.7.2 - Forest tilled system, in particular: & & $\begin{array}{c}6 / \\
(63.7 \% \ldots . .79 .5 \%]\end{array}$ \\
\hline $\begin{array}{l}\text { V.7.2.1 - Broad-leaved forest tilled system, incl. according } \\
\text { to surface slope: }\end{array}$ & & $\begin{array}{c}6 / \\
(63.7 \% \ldots 69.0 \%]\end{array}$ \\
\hline V.7.2.1.1 - slightly sloping & TILLED BR.-L. FORESTS SL. SL. - V.7.2.1.1 & $6 / 64.3 \%$ \\
\hline V.7.2.1.2 - moderately sloping & TILLED BR.-L. FORESTS MOD. SL. - V.7.2.1.2 & $6 / 65.3 \%$ \\
\hline V.7.2.1.3 - middling sloping & TILLED BR.-L. FORESTS MID. SL. - V.7.2.1.3 & $6 / 66.4 \%$ \\
\hline V.7.2.1.4 - essentially sloping & TILLED BR.-L. FORESTS ESS. SL. - V.7.2.1.4 & $6 / 67.4 \%$ \\
\hline V.7.2.1.5 - greatly sloping & TILLED BR.-L. FORESTS GR. SL. - V.7.2.1.5 & $6 / 68.5 \%$ \\
\hline $\begin{array}{l}\text { V.7.2.2 - Mixed forest tilled system, incl. according } \\
\text { to the surface slope: }\end{array}$ & & $\begin{array}{c}6 / \\
(69,0 \% \ldots .74,3 \%]\end{array}$ \\
\hline V.7.2.2.1 - slightly sloping & TILLED MIXED FORESTS SL. SL. - V.7.2.2.1 & $6 / 69.6 \%$ \\
\hline V.7.2.2.2 - moderately sloping & TILLED MIXED FORESTS MOD. SL. - V.7.2.2.2 & $6 / 70.6 \%$ \\
\hline V.7.2.2.3 - middling sloping & TILLED MIXED FORESTS MID. SL. - V.7.2.2.3 & $6 / 71.7 \%$ \\
\hline V.7.2.2.4 - essentially sloping & TILLED MIXED FORESTS ESS. SL. - V.7.2.2.4 & $6 / 72.7 \%$ \\
\hline V.7.2.2.5 - greatly sloping & TILLED MIXED FORESTS GR. SL. - V.7.2.2.5 & $6 / 73.8 \%$ \\
\hline $\begin{array}{l}\text { V.7.2.3 - Coniferous forest tilled system, incl. } \\
\text { according to surface slope: }\end{array}$ & & $\begin{array}{c}6 / \\
(74.3 \% \ldots . .79 .5 \%]\end{array}$ \\
\hline
\end{tabular}




\begin{tabular}{|c|c|c|}
\hline Code and name of LULC systems for different levels & LULC systems' short name and code & $\begin{array}{l}\text { Anthropization extent for } \\
\text { physic-geographic taxon * }\end{array}$ \\
\hline 1 & 2 & 3 \\
\hline V.7.2.3.1 - slightly sloping & TILLED CONIF. FORESTS SL. SL. - V.7.2.3.1 & $6 / 74.8 \%$ \\
\hline V.7.2.3.2 - moderately sloping & TILLED CONIF. FORESTS MOD. SL. - V.7.2.3.2 & $6 / 75.9 \%$ \\
\hline V.7.2.3.3 - middling sloping & TILLED CONIF. FORESTS MID. SL. - V.7.2.3.3 & $6 / 76.9 \%$ \\
\hline V.7.2.3.4 - essentially sloping & TILLED CONIF. FORESTS ESS. SL. - V.7.2.3.4 & $6 / 78.0 \%$ \\
\hline V.7.2.3.5 - greatly sloping & TILLED CONIF. FORESTS GR. SL. - V.7.2.3.5 & $6 / 79.0 \%$ \\
\hline $\mathrm{VI}$ - Hydrotechnical-hydromelioration system, in particular: & & $5 a, 6$ \\
\hline VI.1 - Drainage-irrigation system & DRAINAGE-IRRIGATION - VI.1 & $5 a / 52.8 \%$ \\
\hline VI.2 - Drainage system & DRAINAGE - VI.2 & $6 / 65.2 \%$ \\
\hline $\begin{array}{l}\text { VI.3 - System of geo-negative hydromelioration } \\
\text { consequences }\end{array}$ & GEO-NEG. HYDROMELIORATION - VI.3 & $6 / 79.5 \%$ \\
\hline $\begin{array}{l}\text { VII - Recreational system (incl. sport, leisure, health- } \\
\text { improving facilities etc.) }\end{array}$ & RECREATION - VII & $6 / 67.0 \%$ \\
\hline VIII - Residential system, in particular: & & 6,7 \\
\hline VIII.1 - Village (discontinuous built-up) system & VILLAGES - VIII.1 & $6 / 63.8 \%$ \\
\hline $\begin{array}{l}\text { VIII.2 - City-town (continuous built-up) system, incl. cit- } \\
\text { ies-towns with residents' number (in thousands of people): }\end{array}$ & & $\begin{array}{c}7 / \\
(79.5 \% \ldots 100 \%]\end{array}$ \\
\hline VIII. $2.1-\leq 10$ & CITIES-TOWNS - VIII.2.1 & $7 / 80.8 \%$ \\
\hline VIII.2.2 - (10...20] & CITIES-TOWNS - VIII.2.2 & $7 / 83.4 \%$ \\
\hline VIII.2.3 - (20...50] & CITIES-TOWNS - VIII.2.3 & $7 / 85.9 \%$ \\
\hline VIII.2.4- (50...100] & CITIES-TOWNS - VIII.2.4 & $7 / 88.5 \%$ \\
\hline VIII.2.5 - (100...200] & CITIES-TOWNS - VIII.2.5 & $7 / 91.0 \%$ \\
\hline VIII.2.6 - (200...500] & CITIES-TOWNS - VIII.2.6 & $7 / 93.6 \%$ \\
\hline VIII.2.7 - $(500 \ldots 1,000]$ & CITIES-TOWNS - VIII.2.7 & $7 / 96.2 \%$ \\
\hline VIII.2.8 - > 1,000 & CITIES-TOWNS - VIII.2.8 & $7 / 98.7 \%$ \\
\hline IX - Industrial-construction system & INDUSTRY-CONSTRUCTION - IX & $7 / 82.5 \%$ \\
\hline$X-M i n i n g ~ s y s t e m$ & MINING - X & $7 / 89.8 \%$ \\
\hline XI - Transport-communication system, incl.: & & $4,6,7$ \\
\hline XI.1 - Dirt (country) roads & TRANSPORT-COMMUNICATIONS - XI.1 & $4 / 44.8 \%$ \\
\hline XI.2 - Improved dirt roads & TRANSPORT-COMMUNICATIONS - XI.2 & $6 / 71.6 \%$ \\
\hline XI.3 - Highways, low voltage transmission lines & TRANSPORT-COMMUNICATIONS - XI.3 & $7 / 82.9 \%$ \\
\hline $\begin{array}{l}\text { XI.4 - Improved highways, narrow-gauge railways, } \\
\text { medium voltage transmission lines }\end{array}$ & TRANSPORT-COMMUNICATIONS - XI.4 & $7 / 89.7 \%$ \\
\hline $\begin{array}{l}\text { XI.5 - Superhighways, broad-gauge railways, high voltage } \\
\text { transmission lines }\end{array}$ & TRANSPORT-COMMUNICATIONS - XI.5 & $7 / 96.6 \%$ \\
\hline $\begin{array}{l}\text { XII - System of open spaces with little or no } \\
\text { vegetation, in particular: }\end{array}$ & & 1,2 \\
\hline XII.1 - Bare rock system & BARE ROCKS - XII.1 & $1 / 12.6 \%$ \\
\hline XII.2 - Sand system & SANDS - XII.2 & $2 / 22.1 \%$ \\
\hline XII.3 - Sparsely vegetated system & SPARSE VEGETATION - XII.3 & $2 / 26.0 \%$ \\
\hline XIII - Heterogeneous and other systems, in particular: & & $2,4 a, 5 a$ \\
\hline XIII.1 - Transitional woodland-shrub-herb system & WOODLANDS-SHRUBS-HERBS - XIII.1 & $2 / 26.0 \%$ \\
\hline XIII.2 - Agro-forestry system & AGRO-FORESTRY - XIII.2 & $4 a / 44.8 \%$ \\
\hline $\begin{array}{l}\text { XIII.3 - System of agriculture with significant areas of } \\
\text { natural vegetation }\end{array}$ & AGRO-NATURAL VEGETATION - XIII.3 & $5 a / 57.1 \%$ \\
\hline
\end{tabular}

* $1 \ldots 7$ - the codes of anthropization extent category in the Table $1 / 7.9 \% \ldots 100 \%$ - the partial anthropization indexes $I_{\text {ANT,E, }}$ in the formula (1), $\%$ 
LULC systems were defined. This division reflected the general thesis that the greater is the slope of tilled forest and/or non-forest territory the worse are the geoecological consequences of such tilling.

The identification of the system of geoecological-negative or, briefly, geo-negative hydromelioration consequences set the goal to model and to assess some possible consequences of such land use. They are irrigation erosion, secondary soil resalting, peat shrinkage, accelerated deflation etc.

The ranking of the existing in the implementation megaregion 51 from 55 operating LULC systems of the Table 3 was realized in the so-called area quasi-spectrum presented further in the Fig.4. Such ranking uses the increase of LULC systems' partial anthropization indexes.

\section{Implementation Model Results}

The obtained model results were illustrated, firstly, by digital choropleth presented in the Fig.3. This choropleth displays random fields of the implementation megaregion's anthropization extent. Such extent is simulated by the anthropization indexes $I_{A N T^{* *}}$. These indexes are calculated according to the formula (1) and average-weighted for $1 \mathrm{~km}^{2}$ raster cells. The choropleth represents the simulated background for comprehensive analysis. It should cover the peculiarities, consequences and factors concerning the process of physic-geographic taxons' anthropization at the different territorial levels. The choropleth also depicts the created possibility of prospective distinguishing the new by content and rank taxons. Such taxons will be the units of already geoecological zoning and can contain sub-regions etc. This can be realized by the means of specified model delimitation of the formed homogeneous anthropization extent fields. The landscape typology and other imperative attributes of mentioned zoning should be taken into account too.

Secondly, the megaregional so-called area quasi-spectrum was simulated as an operating tool for the anthropization extent analysis (Fig.4). It is a graph

Fig. 3

Digital choropleth of the implementation megaregion's anthropization extent

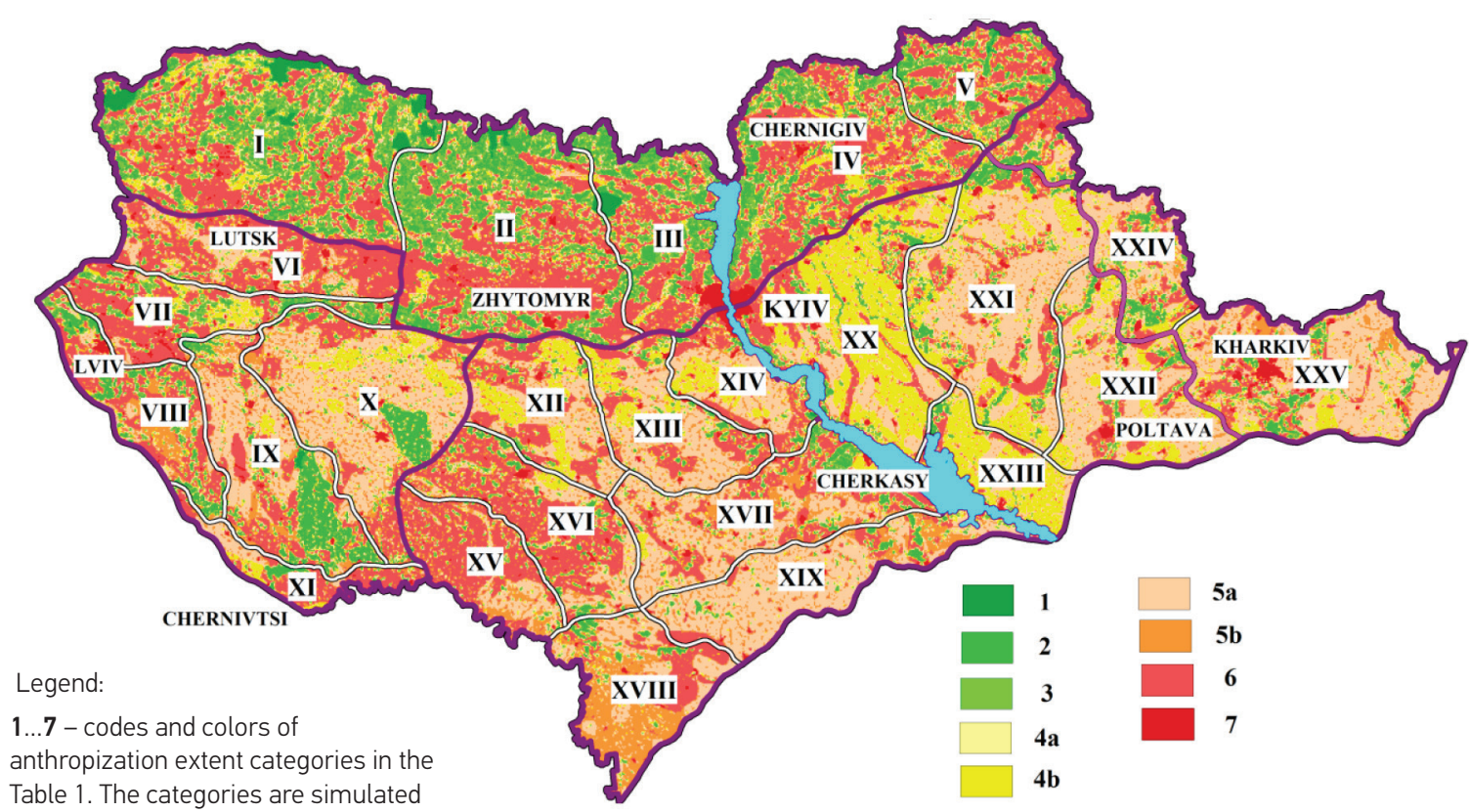

Table 1. The categories are simulated

by the anthropization indexes $I_{\mathrm{ANT}} * *$,

average-weighted for $1 \mathrm{~km}^{2}$ raster cells 
generated according to the formula (2) as follows:

$$
\begin{aligned}
& S_{i}=f\left(\operatorname{LULCS}_{E, i}\right) ; \\
& \left(\sum \mathrm{s}_{\mathrm{i}}\right)_{C A T, j}=f\left(C A T_{A E, L U L C S, j}\right) ;
\end{aligned}
$$

Where: $\operatorname{LULCS}_{E, i}-\mathrm{LULC}$ systems, which are the calculating according to operating scale in the Table 2. These systems are ranked by the increase of their partial anthropization indexes $I_{\text {ANT, }, i}$ in the Table 2; $s_{i}$ - the area percents of each calculating system $L U L C S_{E, i}$ in the megaregion. The sum of all $s_{\mathrm{i}}$ is $100 \%$; $C A T_{A E, L U L C S, j}$ - the anthropization extent categories and/or corresponding to them LULC systems' categories according to the Table 1 . The division of 4 and 5 categories into the subcategories $4 \mathrm{a}$, $4 \mathrm{~b}$ etc. is not used; $\left(\Sigma s_{i}\right)_{C A T, j}$ - the sum of $s_{\mathrm{i}}$ for each category $C A T_{A E, L U L C S, j}$. The sum of all $\left(\Sigma S_{i}\right)_{C A T, j}$ is 100\%. 17

The quasi-spectrum in the Fig. 4 shows that the systems of arable and fallow lands are the dominant LULC systems by negative anthropogenic impact in the megaregion. They are located in the former both non-forest and broad-leaved forest slightly, moderately and middling sloping territories. Village (discontinuous built-up) and recreational systems are also the negatively dominant. They cover jointly with arable systems
Fig. 4

Area quasi-spectrum of the implementation megaregion

NATURE PROTECTION - I.1 BARE ROCKS - XII.1 WETLANDS - II NATURE PROTECTION - I.2 SANDS - XII.2 SPARSE VEGETATION - XII.3 WOODLANDS-SHRUBS-HERBS - XIII.1 BROAD-LEAVED FORESTS - III.1 CONIFEROUS FORESTS - III.2 MIXED FORESTS - III. 3 SHRUBS-HERBS - IV

GRASS.PASTURES \& HAYMAKING - V.1-2 TRANSPORT-COMMUNICATIONS - XI.1 AGRO-FORESTRY - XIII.2

TILLED NON-FORESTS SL. SL. - V.7.1.1 TILLED NON-FORESTS MOD. SL. - V.7.1.2 DRAINAGE-IRRIGATION - VI.1 FRUIT TREES \& VINEYARIS - V.5-6 TILLED NON-FORESTS MIID. SL. - V.7.1.3 AGRO-NATURAL VEGETATION - XIII.3 TILLED NON-FORESTS ESS. SL. - V.7.1.4 VILLAGES - VIII.1
TILLED BR.-L. FORESTS SL. SL. - V.7.2.1.1 DRAINAGE - VI.2

TILLED BR.-L. FORESTS MOD. SL. - V.7.2.1.2 TILLED BR.-L. FORESTS MIID. SL. - V.7.2.1.3 RECREATION - VII

TILLED BR.-L. FORESTS ESS. SL. - V.7.2.1.4 TILLED MIXED FORESTS SL. SL. - V.7.2.2.1 TILLED MIXED FORESTS MOD. SL. - V.7.2.2.2

TRANSPORT-COMMUNICATIONS - XI.2 TILLED MIXED FORESTS MID. SL. - V.7.2.2.3 TILLED MIXED FORESTS ESS. SL. - V.7.2.2.4 TILLED CONIF. FORESTS SL. SL. - V.7.2.3.1 TILLED CONIF. FORESTS MOD. SL. - V.7.2.3.2 TILLED CONIF. FORESTS MII. SL. - V.7.2.3.3 TILLED CONIF. FORESTS ESS. SL. - V.7.2.3.4

GEO-NEG. HYDROMELIORATION - VI.3 CITIES-TOWNS - VIII.2.1 INDUSTRY-CONSTRUCTION - IX TRANSPORT-COMMUNICATIONS - XI.3 CITIES-TOWNS - VIII.2.2 CITIES-TOWNS - VIII.2.3 CITIES-TOWNS - VIII.2.4

TRANSPORT-COMMUNICATIONS - XI.4 MINING - $\mathbf{X}$ CITIES-TOWNS - VIII.2.5 CITIES-TOWNS - VIII.2.6 CITIES-TOWNS - VIII.2.7 TRANSPORT-COMMUNICATIONS - XI.5 CITIES-TOWNS - VIII.2.8

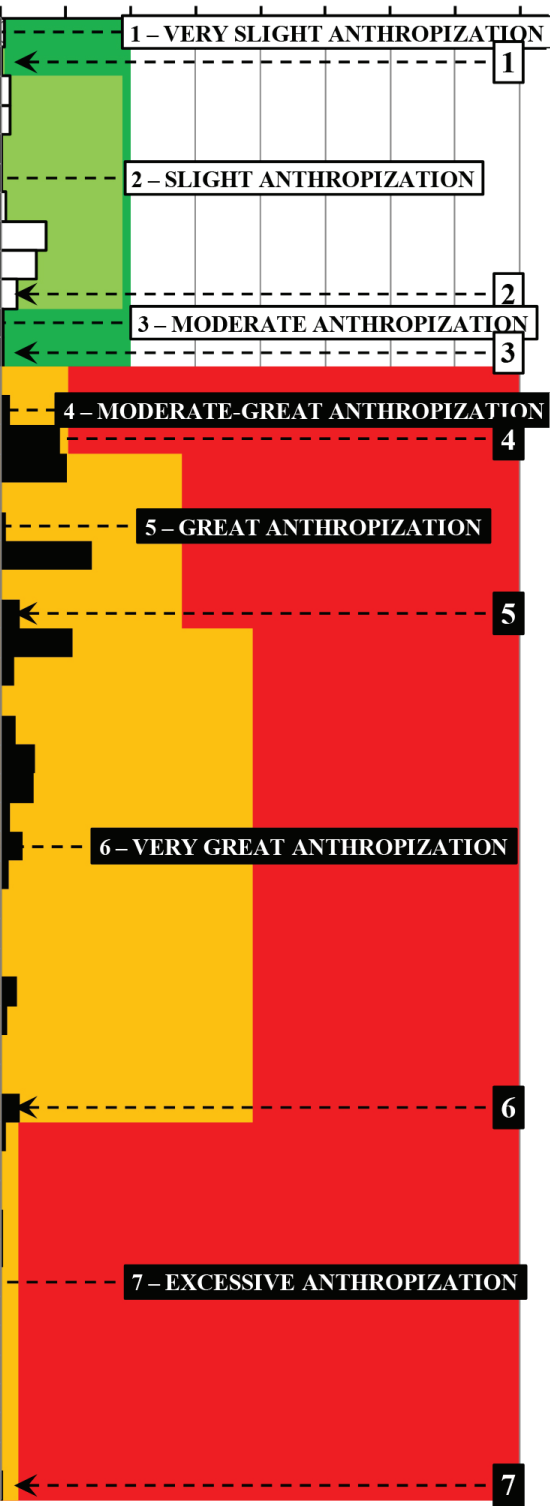

Symbols:

1 ....7 with pointers - the upper limits of anthropization extent categories and/or corresponding to them LULC systems' categories according to the Table 1; and $\quad$ - the sums of $s_{i}$ in each category $\left(\left(\Sigma s_{i}\right)_{C A T,}, \%\right)$ for, in accordance, geo-positive $(\square)$ and geonegative ( $\square$ ) LULC systems; and - the total area percent sums of such systems; the short names and codes of $L U L C S_{E, j}-$ from the Table 2 


\section{Table 3}

Results of anthropization extent modeling for Ukrainian physic-geographic areas and districts

\begin{tabular}{|c|c|c|}
\hline $\begin{array}{c}\text { Code and name of physic-geographic } \\
\text { area (see Fig.2) * }\end{array}$ & $\begin{array}{l}I_{A N T^{* *}} \text { of area } \\
\text { (its districts) }{ }^{* *}\end{array}$ & $\begin{array}{l}\text { Category code and extent of anthropization } \\
\text { for area (its districts) (see Table 1) }\end{array}$ \\
\hline 1 & 2 & 3 \\
\hline | Volynsko-Poliska 1) & $48.2 ;[39.2 \ldots 57.9]$ & $\begin{array}{l}4 b-\text { high-categorical moderate-great }(3-\text { moderate ... } \\
5 b \text { - high-categorical great) }\end{array}$ \\
\hline II Zhytomyrsko-Poliska 1) & $50.9 ;[36.9 \ldots 64.9]$ & $5 a-$ low-categorical great ( 3 - moderate ... 6 - very great) \\
\hline III Kyivsko-Poliska 1) & $49.9 ;[32.2 \ldots 60.3]$ & $\begin{array}{l}4 b-\text { high-categorical moderate-great }(3-\text { moderate } \ldots \\
5 b-\text { high-categorical great) }\end{array}$ \\
\hline IV Chernihivsko-Poliska 1) & $53.7 ;[43.9 \ldots 62.1]$ & $\begin{array}{l}5 a-\text { low-categorical great ( } 4 a-\text { low-categorical moderate-great ... } \\
5 b-\text { high-categorical great) }\end{array}$ \\
\hline V Novhorod-Siversko-Poliska 1) & $51.5 ;[45.6 \ldots 54.7]$ & $\begin{array}{l}5 a-\text { low-categorical great (4b-high-categorical moderate-great ... } \\
5 a-\text { low-categorical great) }\end{array}$ \\
\hline VI Volynska vysochynna 2) & $60.1 ;[55.3 \ldots 66.5]$ & $5 b$ - high-categorical great (5a - low-categorical great ... 6 - very great) \\
\hline VII Malopoliska 2) & $55.7 ;[46.5 \ldots 67.3]$ & $\begin{array}{l}5 b-\text { high-categorical great }(4 b-\text { high-categorical moderate-great } \\
\ldots 6 \text { - very great) }\end{array}$ \\
\hline VIII Roztotsko-Opilska horbohirna ${ }^{2)}$ & $53.5 ;[45.6 \ldots 61.7]$ & $\begin{array}{l}5 a-\text { low-categorical great ( } 4 b-\text { high-categorical moderate-great ... } \\
5 b \text { - high-categorical great) }\end{array}$ \\
\hline IX Zakhidnopodilska vysochynna ${ }^{2)}$ & $51.5 ;[46.5 \ldots 57.8]$ & $\begin{array}{l}5 a-\text { low-categorical great ( } 4 b-\text { high-categorical moderate-great ... } \\
5 b \text { - high-categorical great) }\end{array}$ \\
\hline X Seredniopodilska vysochynna ${ }^{2)}$ & $53.7 ;[42.1 \ldots 60.5]$ & $\begin{array}{l}5 a-\text { low-categorical great ( } 4 a-\text { low-categorical moderate-great ... } \\
5 b \text { - high-categorical great) }\end{array}$ \\
\hline XI Prut-Dnistrovska vysochynna ${ }^{2)}$ & $58.2 ;[56.9 \ldots 61.5]$ & $\begin{array}{l}5 b-\text { high-categorical great (5a - low-categorical great ... } \\
5 b-\text { high-categorical great) }\end{array}$ \\
\hline $\begin{array}{l}\text { XII Pivnichno-Zakhidna Prydniprovska } \\
\text { vysochynna }{ }^{3)}\end{array}$ & $55.5 ;[54.9 \ldots 55.8]$ & $5 a-$ low-categorical great (5a - low-categorical great) \\
\hline $\begin{array}{l}\text { XIII Pivnichno-Skhidna Prydniprovska } \\
\text { vysochynna }{ }^{3)}\end{array}$ & $54.9 ;[53.7 \ldots 56.2]$ & $5 a-$ low-categorical great (5a - low-categorical great) \\
\hline XIV Kyivska vysochynna ${ }^{3)}$ & $56.0 ;[54.0 \ldots 56.8]$ & $5 a-$ low-categorical great (5a - low-categorical great) \\
\hline $\begin{array}{l}\text { XV Prydnistrovsko- Skhidnopodilska } \\
\text { vysochynna }^{3)}\end{array}$ & $60.9 ;[55.9 \ldots 62.6]$ & $\begin{array}{l}5 b-\text { high-categorical great (5a - low-categorical great ... } \\
5 b-\text { high-categorical great) }\end{array}$ \\
\hline XVI Serednobuzka vysochynna ${ }^{3)}$ & $58.3 ;[57.4 \ldots 61.3]$ & $5 b-$ high-categorical great (5b-high-categorical great) \\
\hline $\begin{array}{l}\text { XVII Tsentralnoprydniprovska } \\
\text { vysochynna }^{3)}\end{array}$ & $56.3 ;[49.8 \ldots 58.4]$ & $\begin{array}{l}5 a-\text { low-categorical great (4a - low-categorical moderate-great ... } \\
5 b \text { - high-categorical great) }\end{array}$ \\
\hline XVIII Pivdennopodilska vysochynna ${ }^{3)}$ & $57.2 ;[54.9 \ldots 61.1]$ & $\begin{array}{l}5 b-\text { high-categorical great (5a - low-categorical great ... } \\
5 b-\text { high-categorical great) }\end{array}$ \\
\hline XIX Pivdennoprydniprovska vysochynna ${ }^{3)}$ & $55.2 ;[54.2 \ldots 56.0]$ & 5a - low-categorical great (5a - low-categorical great) \\
\hline $\begin{array}{l}\text { XX Pivnichnoprydniprovska terasova } \\
\text { nyzovynna }{ }^{4)}\end{array}$ & $52.1 ;[48.5 \ldots 56.3]$ & $\begin{array}{l}5 a-\text { low-categorical great }(4 b-\text { high-categorical moderate-great ... } \\
5 a-\text { low-categorical great })\end{array}$ \\
\hline XXI Pivnichnopoltavska vysochynna ${ }^{4)}$ & $52.5 ;[46.3 \ldots 53.1]$ & $\begin{array}{l}5 a-\text { low-categorical great (4b-high-categorical moderate-great ... } \\
5 a \text { - low-categorical great) }\end{array}$ \\
\hline XXII Skhidnopoltavska vysochynna ${ }^{4)}$ & $52.7 ;[51.6 \ldots 53.5]$ & $5 a-$ low-categorical great (5a - low-categorical great) \\
\hline $\begin{array}{l}\text { XXIII Pivdennoprydniprovska terasova } \\
\text { nyzovynna }{ }^{4)}\end{array}$ & $50.7 ;[50.0 \ldots 51.1]$ & $\begin{array}{l}5 a-\text { low-categorical great (4b-high-categorical moderate-great ... } \\
5 a-\text { low-categorical great) }\end{array}$ \\
\hline XXIV Sumska skhylovo-vysochynna 5) & $53.8 ;[51.8 \ldots .56 .0]$ & $5 a-$ low-categorical great (5a - low-categorical great) \\
\hline $\begin{array}{l}\text { XXV Kharkivska } \\
\text { skhylovo-vysochynna }{ }^{5)}\end{array}$ & $54.2 ;[50.2 \ldots 57.4]$ & $\begin{array}{l}5 a-\text { low-categorical great (4b-high-categorical moderate-great ... } \\
5 a \text { - low-categorical great) }\end{array}$ \\
\hline
\end{tabular}

* The names of the physic-geographic areas, regions and zones are given according to (National Atlas, 2007); ${ }^{* *}{ }_{\text {AN }^{* *}}$ - the average-weighted index of landscape/taxon anthropization according to the formula (1);

1) zone of mixed (coniferous/broad-leaved) forests, Poliskyi region; ${ }^{2)}$ zone of broad-leaved forests, Zakhidnoukrainskyi region; ${ }^{3)}$ zone of forest-steppe, Podilsko-Prydniprovskyi region; 4) zone of forest-steppe, Livoberezhnodniprovskyi region; ${ }^{5}$ zone of forest-steppe, Skhidnoukrainskyi region (see the Fig. 1-2) 
over $50 \%$ of the megaregional territory. The environmentally-friendly impact in the region is caused mostly by broad-leaved, coniferous and mixed forest systems and also nature-protection and wetland systems. They occupy together more than $19 \%$ of the megaregional area. The consequences of such anthropogenic impact distribution are the following at the level of physic-geographic areas' and districts' anthropization extent (Table 3, Fig.4-6).

Fig. 4

Digital choropleth of the physic-geographic areas' anthropization extent

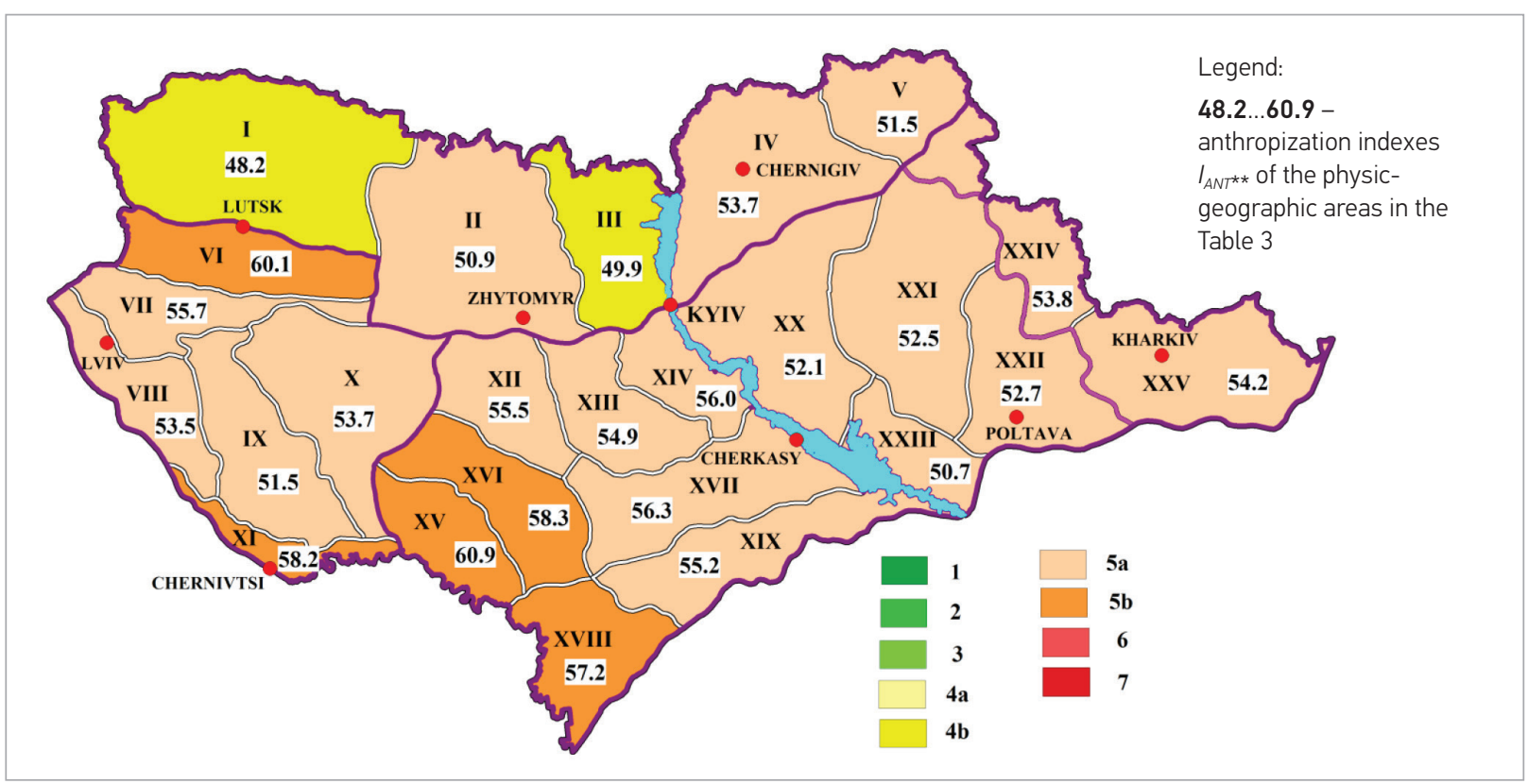

Fig. 5

Digital choropleth of the megaregional physic-geographic areas' anthropization ratings

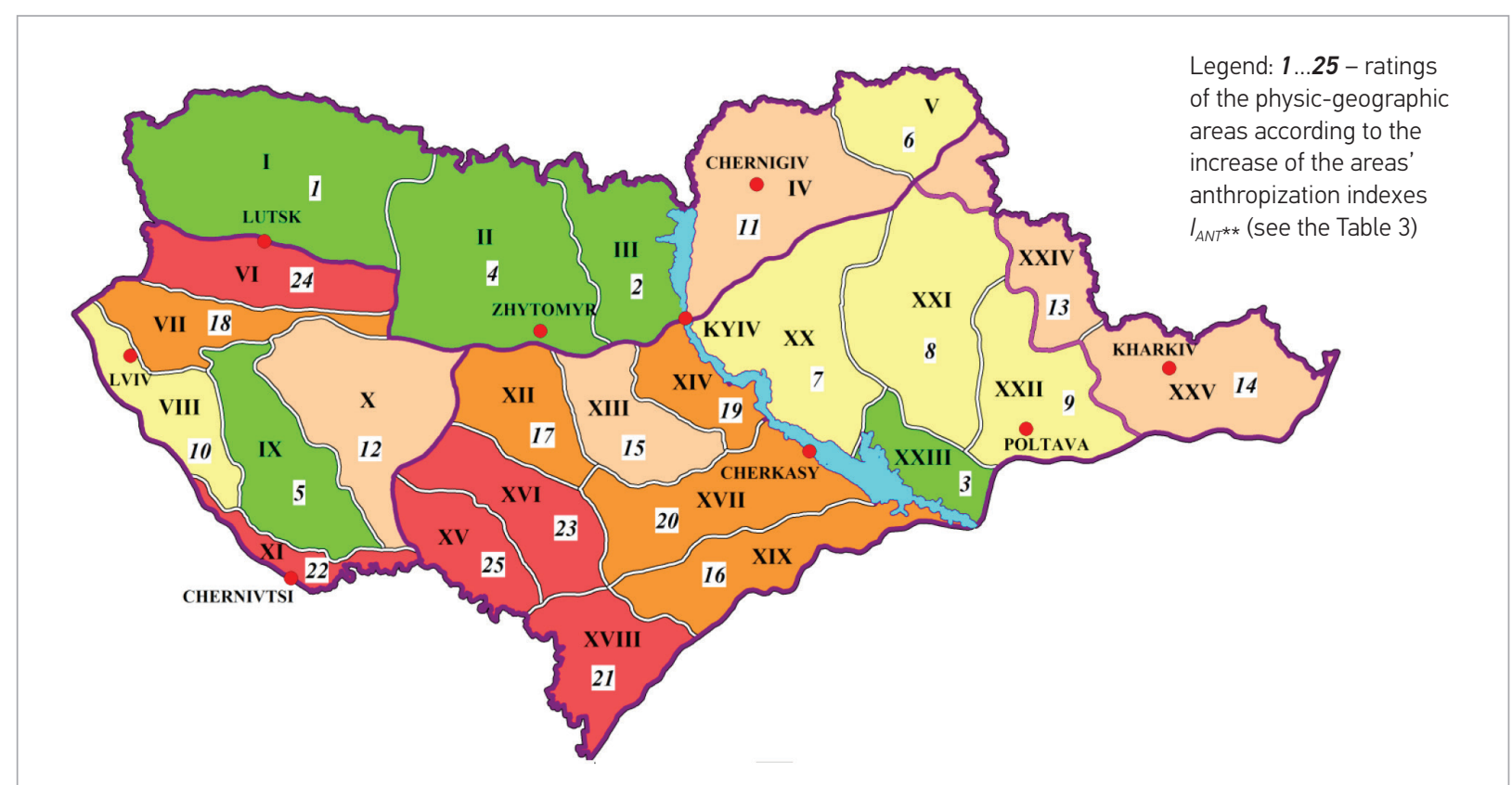


Fig. 6

Digital choropleth of the physic-geographic districts' anthropization extent

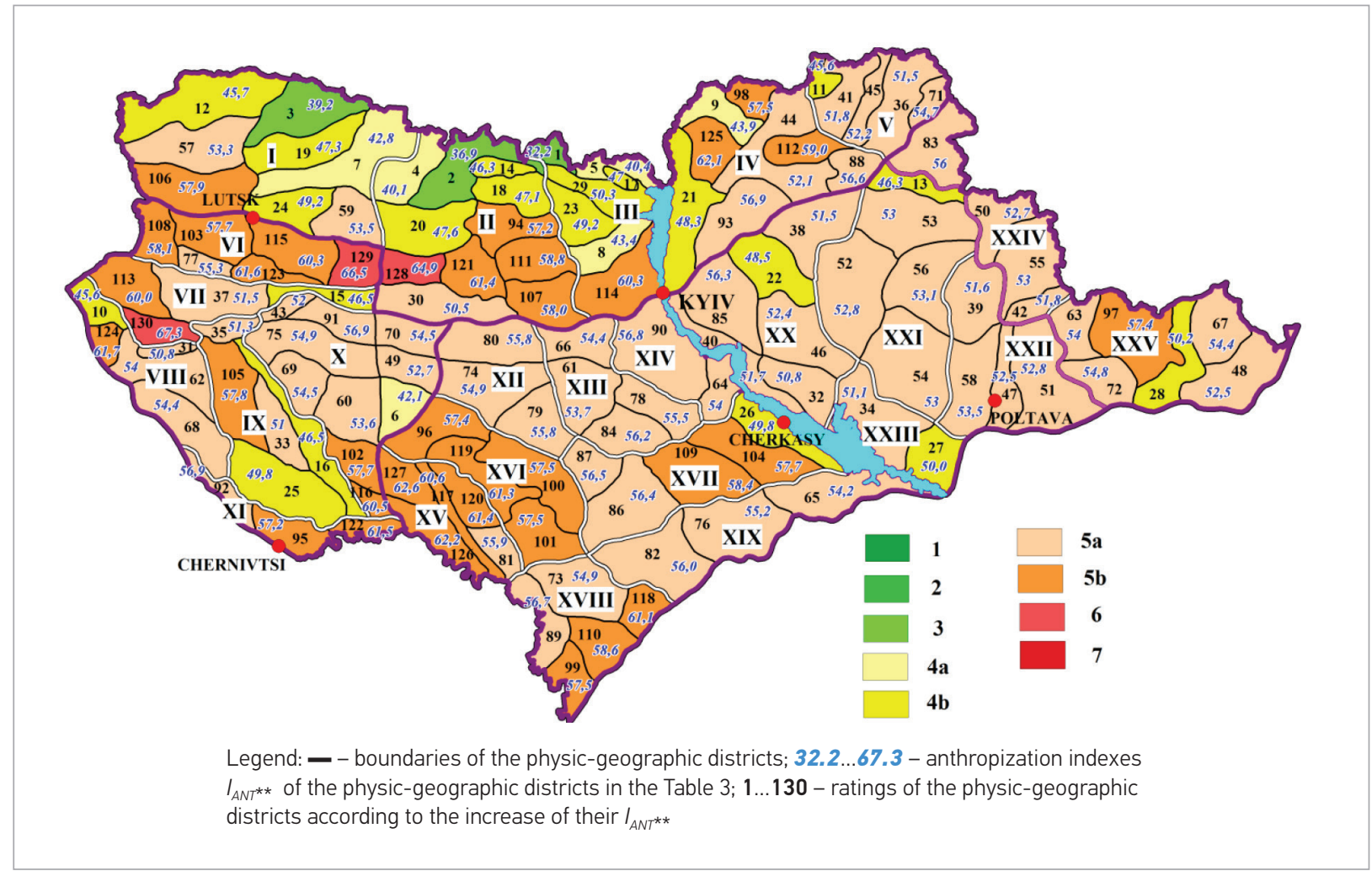

The implementation model results indicate that only in 2 from 25 physic-geographic areas moderate-great anthropization was simulated. In 18 areas anthropization are low-categorical and in 5 high-categorical great (see Fig.4). On the other hand, 3 from 130 physic-geographic districts are characterized by moderate, 6 by low-categorical moderate-great and 20 by high-categorical moderate-great anthropization. In 64 districts anthropization is low-categorical great, in 34 high-categorical great and in 3 very great (see the Fig.6).

Volynska vysochynna area of Zakhidnoukrainskyi broad-leaved forest region and Prydnistrovsko- Skhidnopodilska vysochynna area of Podilsko-Prydniprovskyi forest-steppe region are the worst in megaregion according to their anthropization ratings (see the Fig.5 and the Table 3). The anthropization indexes of these areas exceed the value of $60 \%$. Three physic-geographic districts of Kyivsko-Poliska, Zhytomyrsko-Poliska and Volynsko-Poliska areas are the best by the ratings according to increase of districts' anthropization indexes in the megaregion. Two the worst by such ratings districts are situated in Volynska vysochynna and Malopoliska areas (see the Fig.6 and the Table 3). The anthropization peculiarities shown in the Fig.4-6 are positionally and contently adequate display of the megaregional specificity in land use analyzed in (Samoilenko et al., 2018). The consequences of such land use are altogether unfavorable for the natural environment.

All results represented in the paper indicated the relevance, objectivity and application suitability of the proposed before analytical approaches to the landscape anthropization extent modeling. They can be directly implemented together with organized spatial data bases in megaregional schemes and projects of environmental management. This management may concern not only the specified in the paper megaregion but any physic-geographic taxon for which 
modern SDB can be organized. Mentioned schemes and projects have to be aimed to land use optimization and realization of effective environmental protection measures. Such measures can consist of forests' preservation and restoration, development of nature reserve fund and ecological networks and other proper measures. All of them should be aimed at regulation of anthropogenic load on landscapes in order to reduce it including a transboundary dimension under international landscape-ecological cooperation.

\section{Conclusions}

Previously proposed procedure of anthropization extent modeling for landscapes and/or physic-geographic taxons was implemented for the specified megaregion. It includes Ukrainian physic-geographic zones of mixed and broad-leaved forests and forest-steppe and their lower level components.

The spatial data bases (SDB) for the implementation megaregion were organized by appropriate geoinformation processing of up-to-date open digital spatial data sources. The last contain land cover maps of the European Space Agency and the National Geomatics Center of China. The maps are initially obtained from remote sensing data of satellite programs' set. Other representative electronic sources were also used.

\section{References}

Bossard M. et al. (2000) CORINE land cover technical guide Addendum 2000. Technical report No 40. Copenhagen: EEA (European Environment Agency), 2000, 105 p.

ESA (European Space Agency) (2015) CCl (Climate Change Initiative) Land Cover Map. Available at: http://maps.elie.ucl. ac.be/CCl/viewer/index.php (accessed 31 March 2018).

Eurostat Statistics (2012) Eurostat Statistics Explain: Agri-environmental indicator - landscape state and diversity. Available at: http://ec.europa.eu/eurostat/statistics-explained/ index.php/Archive:Agri-environmental_indicator_-_landscape_state_and_diversity (accessed 31 March 2018).

IOER Monitor (2015) Monitor of Settlement and Open Space Development. Leibniz Institute of Ecological Urban and Regional
The implementation operating scale of anthropization extent for physic-geographic taxons was substantiated and created with statement of its development and implementation peculiarities. This scale relies mainly on the organized megaregional SDB. The scale embodies 55 operating land use and/or land cover systems causing determinate anthropization extent. The extent is presented by the corresponding to mentioned systems anthropization categories and indexes.

The operating scale was strictly implemented for the megaregion. The implementation included the anthropization extent modeling at the level of physic-geographic areas and districts. The interpretation of the obtained model results was carried out. Such results display that the land use consequences are altogether unfavorable for the natural environment of the megaregion.

The all obtained results indicated the relevance and objectivity of proposed approaches to the landscape anthropization extent modeling. The approaches are applicable to schemes and projects of environmental management.

The next step in the research scope of this paper will be to develop and implement the approaches to modeling of one more principal landscape anthropization parameter. Such parameter is the area proportion for geoecological positive and negative LULC systems. The first are still called nature-accentuated or near-to-nature systems. The further development would include also operating scale of the mentioned proportion.

Development. Available at: https://monitor.ioer.de (accessed 31 March 2018).

National Atlas (2007) National Atlas of Ukraine (electronic version, in Ukrainian). Institute of Geography NASU, SRPE "Cartography” et al. / Національний атлас України (електронна версія). Інститут географії НАНУ, ДНВП “Картографія” та ін., 2007.

NGCC (National Geomatics Center of China) (2011) Globeland30 Land Cover Map. Available at: http://www.globallandcover. com/GLC30Download/index.aspx (accessed 31 March 2018).

Osadchyi V., Samoilenko V. et al. (2004) Information management of international Dnipro Basin rehabilitation. Monograph (in Russian). Kyiv, Ukraine: Nika-Center, 152 р. / Осадчий В.И., Самойленко В.Н. и др. Информационный менеджмент 
экологического оздоровления международного бассейна Днепра: монография. К.: Ника-Центр, 2004, 152 с.

Paracchini M.L., Capitani C. (2011) Implementation of a EU wide indicator for the rural-agrarian landscape. JRC scientific and technical reports (EUR 25114 EN-2011). Luxembourg: Publications Office of the European Union, 2011, 89 p.

Samoilenko V. (2002) Probabilistic mathematical methods in geoecology. Manual (in Ukrainian). Kyiv, Ukraine: Nika-Center, 404 р. / Самойленко В.М. Ймовірнісні математичні методи в геоекології: навчальний посібник. К.: НікаЦентр, 2002, 404 с.

Samoilenko V. (2003) Foundations of geoinformation systems. Methodology. Manual (in Ukrainian). Kyiv, Ukraine: Nika-Center, 276 р. / Самойленко B.М. Основи геоінформаційних систем. Методологія: навчальний посібник. К.: Ніка-Центр, 2003, 276 с.

Samoilenko V. et al. (2006) Geoinformation modeling of ecological network. Monograph (in Ukrainian). Kyiv, Ukraine: Nika-Center, 2006, 224 р. / Самойленко B.M. та ін. Геоінформаційне моделювання екомережі: монографія. К.: Ніка-Центр, 2006, 224 с. Available at: http://geo.univ. kiev.ua/images/doc_file/navch_lit/Samojlenko_geoinform.pdf (accessed 31 March 2018).

Samoilenko V., Dibrova I. (2012) Model identification of coastal geosystems. Monograph (in Ukrainian). Kyiv, Ukraine: Nika-Center, 328 р. / Самойленко В.М., Діброва І.О. Модельна ідентифікація берегових геосистем: монографія. К.: НікаЦентр, 2012, 328 с. Available at: http://geo.univ.kiev.ua/ images/doc_file/navch_lit/ Samojlenko_identyfy.pdf (accessed 31 March 2018).

Samoilenko V., Vishnikina L. et al. (2014) Didactics of geography. Monograph (in Ukrainian). Kyiv, Ukraine: Pedahohichna dumka, 586 р. / Самойленко В.М., Вішнікіна Л.П. та ін. Дидактика географії: монографія. К.: Педагогічна думка, 2014, 586 с.

Samoilenko V. et al. (2015a) Modeling of basin geosystems. Monograph (in Ukrainian). Kyiv, Ukraine: SE "Print Service", 208 р. / Самойленко В.М. та ін. Моделювання басейнових геосистем: монографія. К.: ДП “Прінт Сервіс", 2015, 208 c. Available at: http://geo.univ.kiev.ua/images/doc_file/
navch_lit/Samojlenko_urbolad.pdf (accessed 31 March 2018).

Samoilenko V. et al. (2015b) Conceptions for identification of landscapes' anthropization extent: retrospective survey and prospects (in Ukrainian). Physic Geography and Geomorphology, V.4(80): 19-38 / Самойленко В.М. та ін. Концепції ідентифікації міри антропізації ландшафтів: ретроспектива та перспективи. Фізична географія та геоморфологія, 2015, вип.4(80), С.19-38.

Samoilenko V. et al. (2016a) Classification of conceptions for identification of landscapes' anthropization extent (in Ukrainian). Hydrology, Hydrochemistry and Hydroecology, V.1(40): 6-29. / Самойленко B.М. та ін. Систематизація концепцій ідентифікації міри антропізації ландшафтів // Гідрологія, гідрохімія і гідроекологія, 2016, т.1(40), С.6-29.

Samoilenko V. et al. (2016b) Interoperable procedure of anthropization extent' analysis for Ukrainian landscapes (in Ukrainian). Hydrology, Hydrochemistry and Hydroecology, V.2(41): 6-31 / Самойленко В.М. та ін. Інтероперабельна методика аналізу міри антропізації ландшафтів України. Гідрологія, гідрохімія і гідроекологія, 2016, т.2(41), С.6-31.

Samoilenko V. et al. (2017) Modern procedure of landscape anthropization analysis. Problems of Geography, 2017, Vol.1-2: 31-42. Sofia: Bulgarian Academy of Science, National Institute of Geophysics, Geodesy and Geography. Available at: http://geoproblems.eu/wp-content/uploads/2017/10/2017_12/2_samoilenko.pdf (accessed 31 March 2018).

Samoilenko V., Dibrova I. et al. (2018) Anthropization of landscapes. Monograph (in Ukrainian). Kyiv, Ukraine: Nika-Center, 232 р. / Самойленко В.М., Діброва І.О. та ін. Антропізація ландшафтів: монографія. Київ: Ніка-Центр, 2018, 232 c. Available at: http://geo.univ.kiev.ua/images/ doc_file/navch_lit/Antropizazia\%20landchaftiv_Samoylenko.pdf (accessed 31 March 2018).

Walz U., Stein C. (2014) Indicators of hemeroby for the monitoring of landscapes in Germany. Journal for Nature Conservation 22: 279-289. https://doi.org/10.1016/j. jnc.2014.01.007 


\section{Kraštovaizdžio modeliavimas: Ukrainos geografinių taksonų išsaugojimo įgyvendinimas}

Gauta: $2018 \mathrm{~m}$. balandis Priimta spaudai: 2018 m. gegužè

\section{Viktoras Samolenko, Ivanas Dibrova}

Kijevo nacionalinis universitetas, Ukraina

\section{Volodymyras Osadchyi}

Ukrainos hidrometeorologijos institutas, Nacionalinè mokslų akademija, Ukraina

\section{Liubovas Visnina}

V.G. Poltavos nacionalinio pedagoginio universitetas, Ukraina

I nurodytą regioną buvo idiegta antropizės masto modeliavimas kraštovaizdžiams ir (arba) fiziniams-geografiniams taksonams. Tai apima Ukrainos fizikines-geografines mišrių ir plačialapių mišku bei miško stepių zonas. Erdviniu duomenu bazès (angl. SDB) buvo organizuotos regiono igyvendinimui, atnaujinus atvirus skaitmeninius erdvinių duomenų šaltinius atitinkamai geoinformaciniu būdu. Fizinių-geografiniu taksony antropizacijos masto igyvendinimo mastas buvo pagristas ir sukurtas pagal regionini SDB. Skaleje ¡kūnijama 55 žemès naudojimo ir (arba) žemès dangos (LULC) sistemu, dèl kuriu nustatomas antropizmas. Paskutinis pateiktas pagal minètas sistemas antropizacijos kategorijas ir indeksus. Veiklos mastas buvo griežtai taikomas regionui. Igyvendinimas apima antropizacijos masto modeliavimą fizikines-geografines vietoves ir rajonus. Gauta modelio rezultatu interpretacija. Rezultatai rodo, kad žemės naudojimo pasekmès yra nepalankios regiono gamtos aplinkai. lgyvendinimo modelio pasiekimai parodè, kad siūlomu požiūriu i kraštovaizdžio antropizacijos mastą modeliavimas tinkamumas ir objektyvumas. Šie metodai taikomi aplinkosaugos vadybos programoms ir projektams.

Raktiniai žodžiai: kraštovaizdis, erdvinių duomenų bazès, geografinis taksonas. 